\title{
Water balance implications of switching from continuous submergence to flush irrigation in a rice-growing district
}

\author{
Sandra Cesari de Maria, ${ }^{\mathrm{a}, *}$ Michele Rienzner, ${ }^{\mathrm{a}}$ Arianna Facchi, ${ }^{\mathrm{a}}$ Enrico Antonio Chiaradia, ${ }^{\mathrm{a}}$ Marco Romani, \\ Claudio Gandolfi ${ }^{\mathrm{a}}$ \\ a Department of Agricultural and Environmental Sciences (DiSAA), Universitá degli Studi di Milano, 20133 Milan, Italy \\ ${ }^{\mathrm{b}}$ Centro Ricerche sul Riso, Ente Nazionale Risi (ENR), 27030, Castello d'Agogna (PV), Italy
}

\section{A R T I C L E I N F O}

\section{Article history:}

Received 8 August 2015

Received in revised form 22 March

2016

Accepted 24 March 2016

Available online xxx

\section{Keywords}

Rice irrigation

Shallow groundwater

Irrigation district

SWAP model

Scenario analysis

\section{A B S T R A C T}

Studies conducted at the field scale report significant reductions in the irrigation requirements of rice when continuous submergence (CS) is replaced by less water-demanding regimes such as flush-irrigation (FI, i.e. intermittent irrigations of rice growing in non-submerged soils). However, the effects of their extensive application in paddy areas with shallow groundwater is much less studied. We present a scenario analysis investigating the impacts on irrigation requirements induced by a shift from CS to FI in an irrigation district of Northern Italy where rice is the main crop, followed by maize and poplar. The area is characterised by a shallow water Table whose depth fluctuates between two meters (in winter) and less than $1 \mathrm{~m}$ (in summer). We applied a three-stage procedure, where we first analysed present state conditions using the SWAP (Soil, Water, Atmosphere, Plant) model to simulate irrigation deliveries and percolation fluxes. Then, we calibrated an empirical relationship between estimated percolation fluxes and measured depths to groundwater. Finally, we applied this relationship, in combination with the SWAP model, to predict the variation of district irrigation requirements due to a widespread shift from CS to FI. Results show that neglecting the feedback between groundwater recharge due to irrigation and groundwater depth led to overestimating the reduction of irrigation requirements of rice, which decreased from around $80 \%$ when no feedback was considered to around $60 \%$ when it was accounted for. Moreover, increased groundwater depths resulted in higher irrigation requirements for maize with an estimated growth of more than $50 \%$ due to the need of shortening the irrigation turn. These results demonstrate the importance of considering the impacts on the hydrological processes at larger scales when planning the conversion of CS into more efficient field irrigation methods.

(C) 2016 Published by Elsevier Ltd.

\section{Introduction}

The method of flush irrigation, in which rice is irrigated as an upland crop such as wheat or maize, has been tested in different environments (e.g. Belder et al., 2007; Bouman et al., 2005, 2007; Feng et al., 2007; Govindarajan et al., 2008; Kato et al., 2009; Tabbal et al., 2002; Xue et al., 2008). Various authors report that flush irrigation (FI) of rice can reduce irrigation water deliveries by up to $60 \%$, compared to continuous submergence (CS), albeit with a yield loss of $10 \%$ to $30 \%$ (Borrell et al., 1997; Bouman et al., 2005; Tabbal et al., 2002). However, most research on alternative irrigation techniques, to date, has been limited to individual field experiments and there is still the need to assess the large-scale and long-term impacts of flush irrigation (see, e.g., Guerra et al., 1998; Humphreys et al., 2005). One open issue, in particular, refers to the role of the feedback effects on rice irrigation requirement due to the likely increase of groundwater depth when a large-scale shift from CS to FI takes place. Indeed, Belder et al. (2005) and Cabangon et al. (2004) observed that ground-

* Corresponding author.

Email addresses: sandra.cesari@unimi.it (S. Cesari de Maria); michele.rienzner@, unimi.it (M. Rienzner); arianna.facchi@unimi.it (A. Facchi); enrico.chiaradia@, unimi.it (E.A. Chiaradia); m.romani@enterisi.it (M. Romani); claudio.gandolfi@, unimi.it (C. Gandolfi) water depths remained very shallow in various field experiments, while it can be expected that the large-scale adoption of FI or of similar techniques will lead to an increase in groundwater depth, due to reduced recharge (Belder et al., 2004; Mishra et al., 1990). This, in turn, will increase percolation and limit root uptake from groundwater, thus limiting the ultimate reduction in irrigation requirements (Belder et al., 2007; Tabbal et al., 2002). Furthermore, negative impacts on ecosystem services are expected since flooded rice paddies play a key role in sustaining a rich biodiversity, including unique and threatened species (Fernando et al., 2005). In addition to that, also negative impacts on groundwater dependent ecosystems can be expected due to the reduction of percolation fluxes.

The rice area covering about 200,000 ha in the Western Po Valley, Italy, is a typical case of a historical rice district where the pressure to shifting from CS to alternative water management practices has been increasing during recent years (ENR, 2013). Rice in the area has been traditionally grown in bunded fields, that are kept flooded from April to September. The agricultural practice consists of broadcasting pre-germinated seeds over submerged, levelled fields and then maintaining a ponded water depth of about $100 \mathrm{~mm}$ for most of the growing season. Currently, the seasonal irrigation depth averages approximately $3000 \mathrm{~mm}$ (INEA, 2013), but it is quite variable in the area, depending on soil characteristics and groundwater depth. The long-term persistence of a traditional rice cropping system in much of the area has created a very characteristic agro-environment, that has 
been included in the European ecological network NATURA 2000 and in the official list of the European Special Protected Areas (HABITAT Directive, 92/43/EEC). Moreover, the continuous submergence practice is a key factor in the recharge of the phreatic aquifer, which is very shallow over most of the area and feeds many semi-natural springs, called "fontanili", that form a longitudinal strip of groundwater-dependent ecosystems across the area.

The increasing competition for water is motivating the adoption of less water-demanding regimes. Delayed flooding after dry-seeding has increased in recent years in the eastern portion of the area (ENR, 2013). So, too, has the interest in flush irrigation, given its potential to strongly decrease irrigation requirements, contributing to reducing pressures on riverine environments due to abstractions for irrigation, consistent with the objectives of the EU Water Framework Directive (2000/60/EC). On the other hand, however, there is a concern that the widespread adoption of flush irrigation may alter the hydrological regime of surface and groundwater, while having a smaller effect than expected on the total irrigation requirements and especially on the peak irrigation demand.

In this paper, we present a procedure to account for the feedbacks between irrigation deliveries and fluctuations in groundwater depth and we illustrate the results of its application to the analysis of a scenario of shift from CS to FI rice in a pilot agricultural district within the western Po Valley rice area.

\section{Material and methods}

\subsection{Pilot study area and data collection}

The study area is the San Giorgio East district, which comprises about 500 ha located at the centre of the western Po Valley rice area, about $45 \mathrm{~km}$ southwest of the city of Milan (northern Italy). The district is bounded to the west and east by two small streams, Arbogna and Terdoppio, respectively (Fig. 1) and is characterised by nearly homogeneous soils and an average slope of about $1 \%$. The local climate is humid subtropical (Cfa) according to the Köppen climate classification (Köppen 1936), with average temperature of $20^{\circ} \mathrm{C}$ and cumulated rainfall depth of about $360 \mathrm{~mm}$ during the agricultural season (April-September, average over the period 1993-2013). The main soil type of the area is Argic Udipsamments mixed mesic (ERSAL, 1993; USDA, 1975), with a high percentage of sand (Table 1). According to the ROSETTA pedo-transfer functions (Schaap et al., 2001), the saturated hydraulic conductivities of this soil range from $170 \mathrm{~cm} \mathrm{~d}^{-1}$ in the Apg horizon, to $550 \mathrm{~cm} \mathrm{~d}^{-1}$ in the deeper horizon. It is a highly draining soil for CS rice cultivation. However, favourable conditions are created by the shallow groundwater depth, with summer minimums of less than one meter and winter maximums within two meters. Land use includes rice, maize and poplar (Table 2). The rice area has been steadily decreasing in the last years, from $50 \%$ of the district area in 2010 to less than $30 \%$ in 2013, mostly due to an increase in maize production, supported by the construction of a biogas plant nearby.

Table 1.

Profile characteristics of the main agricultural soil type in the San Giorgio East district.

\begin{tabular}{lllllllll}
\hline \multirow{2}{*}{ Horizons $^{\mathrm{a}}$} & $\begin{array}{l}\text { Soil } \\
\text { depth }\end{array}$ & $\begin{array}{l}\text { Coarse } \\
\text { Sand }\end{array}$ & $\begin{array}{l}\text { Medium } \\
\text { Sand }\end{array}$ & $\begin{array}{l}\text { Fine } \\
\text { Sand }\end{array}$ & $\begin{array}{l}\text { Corse } \\
\text { Silt }\end{array}$ & $\begin{array}{l}\text { Fine } \\
\text { Silt }\end{array}$ & $\begin{array}{l}\text { Organic } \\
\text { Clay }\end{array}$ & $\begin{array}{l}\text { Carbon } \\
\end{array}$ \\
& $\mathrm{cm}$ & $\%$ & $\%$ & $\%$ & $\%$ & $\%$ & $\%$ & $\%$ \\
\hline Apg & $0-35$ & 61.3 & 14.2 & 10.7 & 4.3 & 6.4 & 2.9 & 0.80 \\
Bw1 & $40-50$ & 69.4 & 15.9 & 4.2 & 2.5 & 2.5 & 5.6 & 0.20 \\
Bw2 & $50-80$ & 75.5 & 12.9 & 4.5 & 0.9 & 1.3 & 4.9 & 0.10 \\
E\&Bt & $80-230$ & 62.9 & 28.8 & 3.8 & 0.4 & 0.9 & 3.2 & 0.00 \\
\hline
\end{tabular}

a Classification according to USDA (1975).
Table 2.

Surface occupied by each land use (ha) over the years 2010-2013.

\begin{tabular}{lllll}
\hline Year & Maize & Rice & Poplar & Bare \\
\hline 2010 & 86 & 240 & 148 & 24 \\
2011 & 122 & 223 & 136 & 18 \\
2012 & 177 & 163 & 133 & 26 \\
2013 & 197 & 136 & 146 & 19 \\
\hline
\end{tabular}

Irrigation supply is provided by two canals, the S. Giorgio and Daglio canals, which are managed by the Associazione Irrigazione Est Sesia (AIES), an irrigation agency distributing $260 \mathrm{~m}^{3} \mathrm{~s}^{-1}$ for irrigation over an area of more than 300000 ha. Both irrigation canals are fed by surface water diversions and flow rates were monitored daily over the period 2010-2013. According to AIES, approximately one third of the transit flow is lost through seepage from the canal network, due to the high permeability of the soils, and only about $5 \%$ of the remaining share is flowing out from the district, mostly after significant rainfall events. During the same timespan (2010-2013), depth to groundwater was measured at bi-weekly intervals in two piezometers located, respectively, at Ottobiano, close to the southern border of the district, and at Cascina Stella, northeast of the district (Fig. 1).

Rice cultivation is currently performed under continuous submergence, while border irrigation is used for maize, with water deliveries on rotation of 15 days and an irrigation depth of ca. $150 \mathrm{~mm}$ per application. The same method and rotation interval are used also for poplars, but irrigation supplies amounting to ca. $200 \mathrm{~mm}$ per event are provided just in the first four years after planting, as poplars rely on rainfall only throughout the subsequent six years of the average production cycle. The number of irrigations per season, depending on the rainfall pattern, is within a range of 4-6 for maize and 1-3 for poplars.

Hourly values of the agro-meteorological variables including temperature, precipitation, wind speed, solar radiation and relative humidity were acquired from the closest ARPA station, located in Castello d'Agogna, less than $10 \mathrm{~km}$ northwest of the district centre.

Site-specific information on rice development in the area were obtained from a collateral activity that we carried out in experimental rice plots nearby the San Giorgio East district during the years 2012 and 2013 (Chiaradia et al., 2015; Facchi et al., 2013a; BioGesteca, 2014). In the experiment, we collected eddy-covariance flux measurements from CS and FI rice fields and we conducted several monitoring campaigns per season to measure the time patterns of Leaf Area Index (using an A LP-80 AccuPAR Ceptometer), crop height and rooting depth (by a measuring tape).

\subsection{Methodological framework}

Water allocations to the different land uses in the present state (years 2010-2013) were estimated by calculating the water balances per ha of maize, CS rice, poplars and bare soil. A monthly time step was adopted for the analysis to smooth variabilities due to management factors, while still capturing the seasonal fluctuations of water balance terms. The agro-hydrological model SWAP was used, in a semi-distributed way, for all the land uses but CS rice, for which a different approach based on water balance equations was employed. With total irrigation deliveries and the share required by maize and poplars, we could obtain estimates of monthly rice irrigations by solving water budget equations, without the need to implement models simulating the complex water dynamics occurring in flooded rice paddies.

The monthly values of percolation fluxes from each crop area were then used to calibrate an empirical relationship relating recharge 
to groundwater and groundwater depth. Indeed, if it is possible to identify an empirical model describing the relationship between the two variables in the present state, then the model should apply also under scenarios of modified irrigation management practices, provided that the values of the percolation fluxes remain in a similar range. A relationship was therefore identified, calibrated and then used to foresee the groundwater depths of the scenarios.

Finally, the effects of a large-scale transition from CS to FI were analysed paying particular attention to the role played by groundwater depth. Two scenarios were considered: the former (No feedback'- 'NF') assumed that the depth to groundwater did not change from the present condition, while the latter ('Feedback Accounting'- 'FA') specifically considered the fluctuations of groundwater depth triggered by the change in water management of rice areas. Percolation fluxes from the different crop areas, including FI rice, were again simulated using the SWAP model, which was combined with the calibrated relationship between percolation flux and groundwater depth to estimate the time pattern of groundwater depths in FA scenario.

\subsection{Analysis of the present state}

\subsubsection{Maize, poplar and bare areas}

The water balance analysis of maize, poplar and bare areas was performed via model simulation by applying the Soil Water Atmosphere Plant (SWAP) model (Kroes and van Dam, 2003) over the years 2010-2013. SWAP is a well-known physically-based agro-hydrological model that implements a finite difference solution of the Richards' equation:

$$
C(h) \frac{\partial h}{\partial t}=\frac{\partial}{\partial z}\left(K(\theta)\left(\frac{\partial h}{\partial z}+1\right)\right)-S(h)
$$

where $\theta$ is the soil water content [-], $h$ is the soil water potential [L], $C$ is the water capacity $\left[\mathrm{L}^{-1}\right], t$ is time $[\mathrm{T}], z$ is the vertical coordinate taken positive in the upward direction $[\mathrm{L}], K$ is the unsaturated hydraulic conductivity $\left[\mathrm{LT}^{-1}\right]$ and $S$ is the sink term $\left[\mathrm{T}^{-1}\right]$ representing the water extraction by roots and evaporation from the surface soil layer. The water retention curve and the hydraulic conductivity curve are defined through the analytical functions of Van Genuchten (1980) and Mualem (1976). The root water extraction at various depths in the root zone is calculated from potential transpiration, root-length density and reduction from wet or dry conditions according to the reduction functions proposed by Feddes et al. (1978).

Considering the homogeneity of soils in the area, we assumed the same profile to be representative of the whole district and we obtained values of the hydraulic parameters of each horizon using the ROSETTA pedo-transfer functions (Schaap et al., 2001) with a soil bulk density estimated according to Baumer (1990). The hydraulic parameterization of the profile is reported in Table 3. For the numerical solution of the Richards' equation, the profile was discretized into $1-\mathrm{cm}$ compartments up to $60 \mathrm{~cm}$ and into $5-\mathrm{cm}$ compartments up to $230 \mathrm{~cm}$.

The bottom boundary condition was defined by the values of groundwater depth measured at Ottobiano that were linearly interpolated to obtain daily values, while the upper boundary condition was described by evapotranspiration rates, irrigation and precipitation. Potential evapotranspiration was computed according to the PenmanMonteith equation (Allen et al., 1998) with input of daily meteorological data obtained from the weather station in Castello d'Agogna. Potential evapotranspiration was then partitioned into potential soil evaporation and potential crop transpiration based upon leaf area index (LAI) as a function of the crop development stage. With respect to crop development, we adopted the simple crop module instead of the detailed crop growth simulation model WOFOST 6.0 (Spitters et al., 1989; Hijmans et al., 1994), both available in the SWAP model, since the latter requires input of many parameters that could not be calibrated due to lack of information. Sowing dates, harvesting dates and the seasonal patterns of biometric parameters of maize were estimated according to a model based on the temperature sum of each year (Stockle and Nelson 1996; Gandolfi et al., 2010), with reference values of LAI, crop height and rooting depth representative of the Italian environment (Facchi et al., 2013b; Rienzner et al., 2013). The lengths of development stages were thus consistent with the thermic conditions of each year. On the other hand, poplars were modelled using the generic deciduous forest parameterization suggested by Kroes et al. (2008) (crop file provided with SWAP version 3.2.36), since little site-specific information was available. Pressure heads regulating root water uptake (model of Feddes et al., 1978) were modified according to the specific values for poplars found in Lv et al. (2014). For young poplars, specific parameters such as LAI were adapted to account for the smaller crop development. A summary of the crop parameterization adopted for each crop is reported is Table 4.

Irrigation applications were modelled by the irrigation scheduling option of SWAP, with a fixed interval for water supplies equal to 15 days for maize and 30 days for poplars and supplying irrigation depths of $150 \mathrm{~mm}$ and $210 \mathrm{~mm}$ respectively. To reproduce the variability of irrigation events due to the rainfall pattern and thus skip the irrigation in case of high soil moisture, we identified, via calibration, a threshold of $0.13 \mathrm{~cm}^{3} \mathrm{~cm}^{-3}$ at the depth of $10 \mathrm{~cm}$, which determined a number of irrigation events per season within the ranges observed by AIES. The threshold identified suggests that the irrigation is applied even at high soil water content, to avoid the risk of incurring in water stress conditions during the days passing before the next turn. We also verified that no significant transpirative stress occurred since AIES reported that crop water requirements are substantially satisfied under the current irrigation management.

Table 3.

Soil hydraulic parameters of the SWAP simulations.

\begin{tabular}{|c|c|c|c|c|c|c|c|c|}
\hline Layer & Soil depth & Field capacity ${ }^{\mathrm{c}}$ & Saturated water content ${ }^{\mathrm{a}}$ & Residual water content $\mathrm{t}^{\mathrm{a}}$ & Van Genuchten- $\alpha^{a}$ & Van Genuchten- ${ }^{\mathrm{a}}$ & Hydraulic Conductivity $^{\mathrm{b}}$ & Mualem- $\lambda^{b}$ \\
\hline & $\mathrm{cm}$ & $\mathrm{cm}^{3} \mathrm{~cm}^{-3}$ & $\mathrm{~cm}^{3} \mathrm{~cm}^{-3}$ & $\mathrm{~cm}^{3} \mathrm{~cm}^{-3}$ & $\mathrm{~cm}^{-1}$ & - & $\mathrm{cm}^{3} \mathrm{~d}^{-1}$ & - \\
\hline 1 & $0-35$ & 0.13 & 0.34 & 0.04 & 0.041 & 2.2447 & 168.9 & 0.5 \\
\hline 3 & $50-80$ & 0.13 & 0.34 & 0.05 & 0.032 & 2.7794 & 345.3 & 0.5 \\
\hline 4 & $80-230$ & 0.12 & 0.34 & 0.05 & 0.031 & 3.2667 & 550.5 & 0.5 \\
\hline
\end{tabular}

a parameter of the analytical function of Van Genuchten (1980).

b parameter of the analytical function of Mualem (1986)

c $60 \mathrm{hPa}$. 
Table 4.

Crop parameters in input to the simple crop module of SWAP.

\begin{tabular}{|c|c|c|c|c|}
\hline & \multicolumn{3}{|c|}{ Present State and Scenario } & \multirow{2}{*}{$\begin{array}{l}\text { Scenario } \\
\text { Aerobic } \\
\text { Rice }\end{array}$} \\
\hline & Maize & Young Poplar & $\begin{array}{l}\text { Mature } \\
\text { Poplar }\end{array}$ & \\
\hline \multicolumn{5}{|l|}{ Crop } \\
\hline LAI $\max \left(\mathrm{m}^{2} \mathrm{~m}^{-2}\right)$ & $5.20^{\mathrm{c}, \mathrm{h}}$ & $2.00^{\mathrm{e}}$ & $4.00^{\mathrm{d}}$ & $4.70^{b}$ \\
\hline Root depth max (m) & $0.85^{\mathrm{c}, \mathrm{h}}$ & $1.00^{\mathrm{d}}$ & $1.00^{\mathrm{d}}$ & $0.40^{\mathrm{b}}$ \\
\hline $\begin{array}{l}\text { Minimum canopy } \\
\text { resistance }\left(\mathrm{s} \mathrm{m}^{-1}\right)\end{array}$ & $70^{\mathrm{a}}$ & $150^{\mathrm{d}}$ & $150^{\mathrm{d}}$ & $66^{\mathrm{b}}$ \\
\hline \multicolumn{5}{|l|}{$\begin{array}{l}\text { Critical pressure heads } \\
\text { for root water uptake } \\
(\mathrm{hPa})^{\mathrm{kj}}\end{array}$} \\
\hline $\mathrm{h}_{1}$ & $-10^{\mathrm{a}}$ & $0^{\mathrm{f}}$ & $0^{\mathrm{f}}$ & $100^{\mathrm{h}}$ \\
\hline $\mathrm{h}_{2}$ & $-40^{\mathrm{a}}$ & $0^{\mathrm{f}}$ & $0^{\mathrm{f}}$ & $55^{\mathrm{h}}$ \\
\hline $\mathrm{h}_{3 \mathrm{~h}}$ & $-325^{\mathrm{a}}$ & $-330^{\mathrm{f}}$ & $-330^{\mathrm{f}}$ & $-160^{\mathrm{h}}$ \\
\hline $\mathrm{h}_{31}$ & $-600^{\mathrm{a}}$ & $-2000^{\mathrm{f}}$ & $-2000^{\mathrm{f}}$ & $-250^{\mathrm{h}}$ \\
\hline $\mathrm{h}_{4}$ & $-8000^{\mathrm{a}}$ & $-15000^{f}$ & $-15000^{f}$ & $-16000^{\mathrm{h}}$ \\
\hline \multicolumn{5}{|l|}{ Irrigation Scheduling } \\
\hline Timing & Fixed interval & Fixed interval & - & $\begin{array}{l}\text { On } \\
\text { demand }\end{array}$ \\
\hline Irrigation depth (mm) & 150 & 210 & - & 150 \\
\hline Scheduling criteria & $\begin{array}{l}\text { Moisture } \\
\text { content at a } \\
\text { given depth }\end{array}$ & $\begin{array}{l}\text { Moisture content } \\
\text { at a given depth }\end{array}$ & - & $\begin{array}{l}\text { Daily } \\
\text { stress }^{\mathrm{ji}}\end{array}$ \\
\hline Threshold & $\begin{array}{l}0.13 \mathrm{~cm}^{3} \mathrm{~cm}^{-3} \\
\text { at }-10 \mathrm{~cm}\end{array}$ & $\begin{array}{l}0.13 \mathrm{~cm}^{3} \mathrm{~cm}^{-3} \\
\text { at }-10 \mathrm{~cm}\end{array}$ & - & 0.70 \\
\hline
\end{tabular}

a Baroni et al. (2010).

b BioGesteca, 2014.

${ }^{c}$ Facchi et al. (2013b).

d Kroes et al. (2008).

e Kroes et al. (2008) [modified].

${ }^{f}$ Lv et al. (2014).

g Rienzner et al. (2013).

${ }^{\text {h }}$ Singh et al. (2006).

${ }^{\mathrm{i}}$ Ratio between actual evapotranspiration and potential evapotranspiration.

${ }^{\mathbf{j}} \mathrm{h}_{1}$ : pressure head below which roots start to extract water from the soil; $\mathrm{h}_{2}$ : pressure head below which roots extract water at the maximum possible rate; $h_{3 h}$ : pressure head below which roots can no longer extract water at the maximum rate for higher potential transpiration rates; $h_{31}$ pressure head below which roots can no longer extract water at the maximum rate for lower potential transpiration rates; $h_{4}$ : pressure head below which root water uptake ceases (model of Feddes et al., 1978).

\subsubsection{Rice areas}

The amount of irrigation supplied to CS rice was obtained by solving the monthly water balance equation of the irrigation canals network (2):

$$
\begin{aligned}
& Q_{i t t}=Q_{o t}+P_{c t}+i_{r t} A_{r t}+i_{m f} A_{m t}+i_{y f} A_{y t}+\Delta \\
& C_{t}
\end{aligned}
$$

where: $Q_{i, t}$ is the total inflow to the district through the S.Giorgio and Daglio canals $\left[\mathrm{L}^{3}\right] ; Q_{o, t}$ is the total surface outflow from the district $\left[\mathrm{L}^{3}\right] ; P_{c, t}$ is the seepage flux from the canals $\left[\mathrm{L}^{3}\right] ; \Delta C_{t}$ is storage variation in the canals $\left[\mathrm{L}^{3}\right] ; i_{r, t}, i_{m, t}, i_{y, t}$ are the irrigation depths to rice, maize and young poplars respectively $\left[\mathrm{L}^{3} \mathrm{~L}^{-2}\right]$; and $A_{r, t}, A_{m, t}, A_{y, t}$ are the corresponding areas (Table 2 ) $\left[\mathrm{L}^{2}\right]$.

The inflow $Q_{i, t}$ was obtained from measured flow rates of the two canals feeding the district, while the surface outflow $Q_{o, t}$ was considered equal to $5 \%$ of the distributed irrigation amount (i.e. total supply $Q_{i, t}$ minus seepage losses $P_{c, t}$ ) during the irrigation season, and equal to the total supply $Q_{i, t}$ minus seepage losses $P_{c, t}$ outside the irrigation season when no distribution of water takes place. Seepage from the canals, $P_{c, t}$, amounted to $30 \%$ of the inflow $Q_{i, t}$, as suggested by AIES. Values of irrigation for maize and young poplars, $i_{m, t}$ and $i_{y, t}$, were obtained directly from the SWAP simulations described in the previous section. The area occupied by young (irrigated) poplars, $A_{y, t}$, was set equal to $40 \%$ of the total poplar area reported in Table 2 . Finally, we assumed that the variation in the water storage, $\Delta C_{t}$, was negligible compared to the other terms, since the water circulation in the canal network is maintained throughout all the year and the actual free storage capacity is relatively small.

Once obtained rice irrigation from Eq. (2), we derived rice percolation from Eq. (3):

$$
i_{r t}+r_{t}-p_{r t}-e_{r t}=\Delta s_{r t}+\Delta f_{r t}
$$

where: $i_{r, t}$ is the irrigation depth applied $\left[\mathrm{L}^{3} \mathrm{~L}^{-2}\right]$ as computed from Eq. (2); $r_{t}$ is the rainfall depth $\left[\mathrm{L}^{3} \mathrm{~L}^{-2}\right] ; p_{r, t}$ is the net percolation depth $\left[\mathrm{L}^{3} \mathrm{~L}^{-2}\right] ; e_{r, t}$ is the evapotranspiration depth $\left[\mathrm{L}^{3} \mathrm{~L}^{-2}\right] ; \Delta s_{r, t}$ is the specific storage variation in the rooted soil layer $\left[\mathrm{L}^{3} \mathrm{~L}^{-2}\right]$; and $\Delta f_{r, t}$ is the variation of the flooding depth $\left[\mathrm{L}^{3} \mathrm{~L}^{-2}\right]$

Rainfall depth, $r_{t}$ was provided directly by the registrations at the Castello d'Agogna meteorological station assuming a uniform distribution over the district area. The evapotranspiration term, $e_{r, t}$, was derived from the daily estimates obtained with the FAO-Penman-Monteith method (Allen et al., 1998). Reference evapotranspiration was computed using meteorological data collected at the same station, while the crop coefficients $\left(K c_{i n i}, K c_{\text {mid }}, K c_{\text {end }}\right.$; see Allen et al., 1998) for $\mathrm{CS}$ rice were obtained from the rice experiment performed nearby (Chiaradia et al., 2015; BioGesteca, 2014), where specific local values of $K c_{\text {ini }}=0.8, K c_{\text {mid }}=1.1$ and $K c_{\text {end }}=0.9$ were derived from the integration of eddy-covariance flux measurements and Penman-Monteith type models (Facchi et al., 2013a). The $K c$ curve for each of the four years of the study was built using these values in combination with the same growing degree days model adopted also for maize and poplars to simulate the length of the stages in each year (Stockle and Nelson 1996; Gandolfi et al., 2010).

The storage variations, $\Delta s_{t}$ and $\Delta f_{t}$, were considered negligible, except in May and September. In May, $\Delta f_{t}$ was assumed equal to the average depth of submergence $(100 \mathrm{~mm})$ and $\Delta s_{t}$ to the incremental water amount to reach the saturation of the soil profile from the condition prior to submergence. Soil water content prior to submergence was estimated by running a SWAP simulation for bare soil conditions. In September, $\Delta f_{t}$ was assumed equal to minus the depth of submergence and $\Delta s_{t}$ to half of the saturated soil water content. Lateral-flow components are not included since their contribution to the total water balance is not supposed to be relevant due to the flat topography of the area (average slope in the district about 1\%o).

\subsection{Calibrating a relationship between percolation flux and groundwater depth}

The hypothesis behind this stage of the procedure is that the seasonal fluctuations of the groundwater depth observed in the San Giorgio East district were mostly driven by the recharge due to rain and irrigation. We primarily focussed on the seasonal fluctuations of groundwater depth caused by the superposition of fluxes deriving from percolation of irrigation water to the natural groundwater recharge, since the scope of our analysis was not to capture the shortterm fluctuations of the groundwater depth due to single irrigation or rainfall events.

Groundwater dynamics in the district are also influenced by source and sink terms acting at larger spatial scales and not only by the direct recharge from the district. However, the area included between the Agogna and Terdoppio streams, which represent natural boundaries of the underlying phreatic aquifer, is quite homogeneous in terms of land use and irrigation management, hence the seasonal pattern of groundwater fluctuations is expected to be significantly 
uniform in space. This is confirmed by the analysis of the observations at a second piezometer at Cascina Stella (Fig. 1), showing fluctuations very similar to those at the Ottobiano piezometer (correlation coefficient 0.86).

Following the same rationale, we assumed that the average monthly net percolation flux from the district, $p_{s, t}$, was representative of the large-scale pattern of the recharge to the aquifer and we computed its values for the years 2010-2013 considering the net percolation fluxes of the different crops and the channel seepage flux according to Eq. (4):

$$
\begin{aligned}
& p_{s t}=\left(p_{r f} A_{r t}+p_{m t} A_{m, t}+p_{y t} A_{y t}+p_{p t} A_{p t}+p\right. \\
& \left.b A_{b t}+P_{c t}\right) / A
\end{aligned}
$$

where: $p_{r, t}, p_{m, t}, p_{y, t}, p_{p, t}$ and $p_{b, t}$ are the percolations from rice, maize, young poplars, mature poplars and bare soil, respectively $\left[\mathrm{L}^{3} \mathrm{~L}^{-2}\right] ; A_{r, t}$, $A_{m, t}, A_{y, t}, A_{p, t}$ and $A_{b, t}$ are the corresponding areas $\left[\mathrm{L}^{2}\right] ; P_{c, t}$ is the seepage flux from the canals $\left[\mathrm{L}^{3}\right]$ and $A$ is the district surface $\left[\mathrm{L}^{2}\right]$.

Then, we calibrated an empirical relationship between the monthly series of net percolation flux, $p_{s, t}$, and of reference groundwater depth, $d_{t}$, that can be expressed in the quadratic form:

$$
d_{t}=\alpha \times p_{s, t}^{2}+\beta \times p_{s, t}+\gamma
$$

where the first two terms at the right hand-side account for the effect of recharge fluxes, while the third one reflects the background value of groundwater depth, mainly determined by the water levels in the Terdoppio and Agogna streams that represent the aquifer boundaries. The $\alpha, \beta$ and $\gamma$ parameters were least-squares calibrated using the first three years of available data (2010-2012) and validated with data of year 2013. The goodness of the fit was checked using the correlation coefficient and the Nash-Sutcliffe coefficient.

\subsection{Predicting the effects of flush irrigation}

Similarly to the present state, no feedback (NF) and feedback accounting (FA) scenarios involved, first, the estimate of water balance terms for each land use (FI rice, maize, poplars and bare soil) and then the aggregation of results at the district scale. The total gross amount of water $Q_{i, t}$ in Eq. (2) was computed from the net irrigations to the different crops $\left(i_{r, t}, i_{m, t}, i_{y, t}\right)$, taking into account the share of $Q_{i, t}$ that contributes to seepage from the canals, $P_{c, t}$, and surface outflows, $Q_{o, t}$. Finally, the total district percolation was calculated by solving Eq. (4).

\subsubsection{No feedback scenario (NF)}

Estimates for NF scenario were obtained by running the SWAP model with input of the same meteorological data, soil parameterization and bottom boundary conditions used for the present state, since groundwater depth is assumed invariant. Maize and poplars were therefore treated as discussed in Section 3.3.1 and the same modelling scheme was employed also to simulate FI rice crop. Specific crop parameters of FI rice are reported in Table 4. As in the case of maize and young poplar, we assumed that rice fields were flushed intermittently, with a fixed irrigation depth of $150 \mathrm{~mm}$, but water applications were scheduled on demand, because water delivery to rice farmers is currently continuous and we aimed at providing estimates of irrigation requirements to FI rice not constrained by a rotational scheme. The criterion triggering irrigation applications was the maximum allowed daily stress according to which the model schedules an irrigation every time the actual transpiration drops below a specific share of the potential one. We selected a value of 0.70 , which maintained the mean transpirative stress as low as possible, especially in the month of July, and avoided an excessive number of irrigations.

\subsubsection{Feedback accounting scenario (FA-15 and FA-10)}

We examined two cases of feedback accounting. In FA-15, the interval between two subsequent irrigations of maize was 15 days, as in the present state, whereas the interval was shortened to 10 days for FA-10, because a significant stress, especially in the month of July, occurred under FA-15. As in the NF scenario, we used the SWAP model to simulate the water balance terms of all crops. However, groundwater depths of both FA-15 and FA-10 were unknown, so we implemented an enumerative algorithm to identify feasible bottom boundary conditions for the simulations.

The algorithm is based on two assumptions: $i$ ) the changes in percolation during the agricultural season, due to the shift from the CS to FI technique, may alter the amplitude of the seasonal groundwater fluctuation, but do not modify significantly its shape; ii) the effects of the same changes will gradually fade after the end of the irrigation period and they will not influence the minimum value of groundwater depth, occurring in the fallow season.

First, we generated $\mathrm{N}$ patterns of monthly groundwater depth values with summer minimums ranging from $0.50 \mathrm{~m}$ to $2.00 \mathrm{~m}$ with even increments $(\mathrm{N}=16$ and increments of $0.1 \mathrm{~m})$. The winter maximum was fixed at $2.00 \mathrm{~m}$ for all the $\mathrm{N}$ patterns, corresponding to the average winter maximum over the years 2010-2013. The N sets were obtained by applying Eq. (6) to the monthly average data recorded at Ottobiano over the years 2010-2013.

$$
v_{i, j}=\overline{d_{2}}+\left(v_{i, 8}-\overline{d_{2}}\right) \frac{\overline{d_{j}}-\overline{d_{2}}}{\overline{d_{8}}-\overline{d_{2}}} \text { with } v_{i, 8}=2.0-0.1(\mathrm{i}-1)
$$

where: $i=1, \mathrm{~N}$ is the variant index; $j=1,12$ is the month index (from January to December); $v_{i, j}$ is the average value of groundwater depth (m) of variant $i$ in the month $j$; $\bar{d}_{j}$ is the average observed value of groundwater depth $(\mathrm{m})$ in the month $j$ at Ottobiano (subscript ' 2 ' for February and ' 8 ' for August).

We refer to the $\mathrm{N}$ patterns of groundwater depths computed according to Eq. (6) as the a priori variants. These patterns were used as bottom conditions to run as many simulations for each land use of the scenario (i.e. FI rice, maize, young poplar, mature poplar and bare soil). The same simulation period of 2010-2013 was considered.

For each of the $\mathrm{N}$ a priori variants, we obtained the series of irrigation requirements $\left(i_{r, t}, i_{m, t}, i_{y, t}\right)$ that are scheduled by SWAP taking into consideration that specific groundwater depth set as bottom boundary condition. The simulations provided also the monthly specific net percolations $p_{r, t}, p_{m, t}, p_{y, t}, p_{p, t}$ and $p_{b, t}$, which were used to compute $\mathrm{N}$ series of district percolation $p_{s, t}$ through the application of Eq. (4).

Next, we applied the relationship between percolation and groundwater depth (Eq. (5)) with input of the $\mathrm{N}$ series of $p_{s, t}$ in order to obtain as many patterns of groundwater depths. These are referred to as a posteriori patterns. The simulation better accounting for the scenario is the one in which the a priori variant is as close as possible to the a posteriori pattern. In other words, when the a priori and the a posteriori groundwater depths match, the corresponding percolation fluxes are consistent with the bottom boundary condition used as input to the simulation. To identify the best fit between the a priori and a posteriori patterns, we selected the pair with the smallest distance between the two summer minimum depths (Fig. 2). 


\section{Results and discussion}

\subsection{Analysis of the present state}

\subsubsection{SWAP simulations for maize and poplar areas}

The average water use (irrigation plus rainfall) of maize over the period 2010-2013 was about $900 \mathrm{~mm}$, of which $35 \%$ was provided by rainfall and the remaining part was supplied through border irrigations of $150 \mathrm{~mm}$ each on a 15-days turn (Table 5). Significant variations however occurred in 2010, when heavy rainfall during the irrigation period made the irrigation requirements drop to $450 \mathrm{~mm}$ (443 mm of rainfall against an average of $180 \mathrm{~mm}$ over the same period in the years 2011-2013). Instead, actual ET was rather constant at about $460 \mathrm{~mm}( \pm 53 \mathrm{~mm})$, while potential ET was $646 \mathrm{~mm}( \pm 54)$. Although the actual ET was $30 \%$ lower than potential, most of this deficit was due to a decrease of evaporation, since actual transpiration was on average $85 \%$ of potential during the whole period (May to August) and, especially, during the critical month of July when flowering occurs. The transpirative stress in July 2010 was due to excess of water rather than lack of water, as groundwater depths reaching a minimum of $60 \mathrm{~cm}$ in the month of August determined a reduction of the transpiration rate by $27 \%$. The irrigation requirements of young poplars were $630 \mathrm{~mm}$ in the years 2011-2013 and $420 \mathrm{~m}$ in 2010 (Table 5).

\subsubsection{Water balance of rice areas}

The average irrigation requirements for rice, under continuous submergence, ranged from $3400 \mathrm{~mm}$ in 2010 to more than $4300 \mathrm{~mm}$ in 2013 (Table 5), whereas the rice cropped area declined from 240 ha to 136 ha over the same period. The 4-year average irrigation of $3800 \mathrm{~mm}$ is quite high, but consistent, considering the very high sand percentage of the soils and it is in very good agreement with data of INEA (2013), where irrigation depths greater than $4000 \mathrm{~mm}$ are reported for the same area. Moreover, the higher value obtained in 2013 could be due to two different factors both relating to the contraction of the rice area. First, since the replacement of submerged rice fields with border irrigated maize occurred with a sparse pattern, it may have contributed to increasing the local seepage fluxes and then the water requirements per ha of rice. In addition, it is possible that the operational management of the irrigation distribution still had to fully adjust to the changes in water requirements occurring after the contraction of rice area, since the water supply in the district has been planned for many decades under conditions of predominance of CS rice. This inertia in adaptation implies that more water than the amount actually needed would have been diverted.

Evapotranspiration from rice in the months from May to August amounted to $607 \mathrm{~mm}$ on average and was assumed equal to potential ET, since flooding conditions are maintained throughout the growing season. The net percolation trend reflected that of irrigation with an overall increase from 2010 to 2013 and an average value of $3200 \mathrm{~mm}$

Table 5.

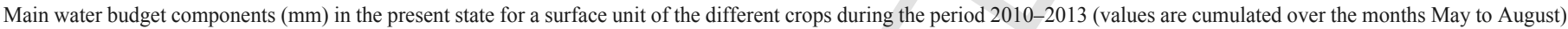

\begin{tabular}{|c|c|c|c|c|c|c|}
\hline & Crop & Rain & Irrigation & Potential ET & Actual ET & Net Percolation \\
\hline \multirow[t]{4}{*}{2010} & Maize & 443 & 450 & 575 & 386 & 356 \\
\hline & Continuously Submerged rice & & 3399 & 537 & 537 & 2942 \\
\hline & Young poplar & & 420 & 450 & 364 & 309 \\
\hline & Mature Poplar & & 0 & 442 & 393 & -145 \\
\hline \multirow[t]{4}{*}{2011} & Maize & 200 & 750 & 632 & 449 & 434 \\
\hline & Continuously Submerged rice & & 3882 & 608 & 608 & 3175 \\
\hline & Young poplar & & 630 & 497 & 270 & 454 \\
\hline & Mature poplar & & 0 & 491 & 338 & -221 \\
\hline \multirow[t]{4}{*}{2012} & Maize & 148 & 750 & 694 & 480 & 339 \\
\hline & Continuously Submerged rice & & 3904 & 646 & 646 & 3097 \\
\hline & Young poplar & & 630 & 520 & 291 & 380 \\
\hline & Mature poplar & & 0 & 510 & 383 & -329 \\
\hline \multirow[t]{4}{*}{2013} & Maize & 195 & 750 & 682 & 510 & 353 \\
\hline & Continuously Submerged $\mathrm{r}$ & & 4373 & 636 & 636 & 3630 \\
\hline & Young poplar & & 630 & 512 & 328 & 390 \\
\hline & Mature poplar & & 0 & 501 & 415 & -320 \\
\hline \multirow[t]{4}{*}{$2010-2013^{\mathrm{a}}$} & Maize & $247( \pm 133)$ & $675( \pm 150)$ & $646( \pm 54)$ & $456( \pm 53)$ & $371( \pm 43)$ \\
\hline & Continuously Submerged rice & & $3889( \pm 398)$ & $607( \pm 49)$ & $607( \pm 49)$ & $3211( \pm 295)$ \\
\hline & Young poplar & & $578( \pm 105)$ & $495( \pm 31)$ & $313( \pm 41)$ & $383( \pm 60)$ \\
\hline & Mature poplar & & $0( \pm 0)$ & $486( \pm 30)$ & $382( \pm 32)$ & $-254( \pm 87)$ \\
\hline
\end{tabular}

\footnotetext{
${ }^{a}$ Averages and standard deviations over the period.
} 
over the years considered. Such downward water fluxes provided a significant recharge to groundwater and were responsible for the shallow water table in the summer.

\subsubsection{Water balance of the conveyance and distribution system}

The total monthly inflow to the conveyance and distribution system during the irrigation season (from May through August) reflected the time pattern of the crop water requirements in the different years. There was a significant inter-annual variability due both to the differences in the meteorological conditions and to the modifications of the land use (Table 6). In May 2010, $200 \mathrm{~mm}$ of rainfall were received, thus reducing the crop irrigation requirements; in 2013 a cold, wet spring delayed the start of the irrigation season, such that the peak demand, usually occurring in July, was in August. Overall, there was a trend of decreasing allocations to rice and increasing to maize, due to the expansion of maize areas and the contraction of rice ones. In May, the water volume allocated to rice was quite variable $\left(1340 \pm 704\right.$ thousands $\left.\mathrm{m}^{3}\right)$, while in the remaining months a more constant amount was provided to satisfy rice water requirements (on average, 1.757, 2099 and 2080 thousands $\mathrm{m}^{3}$ in June, July and August, respectively). Water allocation to maize was null in May and relatively small in August, while it rapidly increased in June and July amounting to an average of $436( \pm 154)$ and $404( \pm 207)$ thousands $\mathrm{m}^{3}$, respectively. The share of water allocated to poplars from June to August remained very small and fairly constant throughout the years. In contrast, the seepage losses from the unlined channel network took a huge portion of the total inflow, which we assumed equal to $30 \%$ of the inflow in each month; this loss rate was derived from estimates provided by AIES based on periodic monitoring of the conveyance efficiency in several channel reaches in the area.

\subsection{Relationship between percolation flux and groundwater depth}

From estimates of the amounts of water percolating from each land use in the present state, it was possible to compute the monthly district percolations representing the recharge to groundwater (Eq. (4)). These monthly net percolation fluxes, $p_{s, t}$ (simulated), with the corresponding monthly reference groundwater depths $d_{t}$ (measured), were used to calibrate the three parameters, $\alpha, \beta$ and $\gamma$ of Eq. (5), obtaining:

$$
d_{t}=0.92 \times p_{s, t}^{2}-2.32 \times p_{s, t}+2.06
$$

The correlation coefficient $\mathrm{R}^{2}$ is of 0.86 in the calibration (2010-2012) and 0.90 in the validation (2013). The pairs $\left(p_{s, t,} d_{t}\right)$ and the graphical representation of Eq. (7) are shown in Fig. 3.

The comparison of the time pattern of the measured groundwater depths with the ones obtained from Eq. (7) using simulated percolation fluxes $p_{s, t}$ as inputs is shown in Fig. 4 for the whole four-year period. The agreement between the two patterns, as expressed by the Nash-Sutcliffe index, is satisfactory $(0.87$ and 0.82 in the calibration and validation respectively). The validity of the model has been also checked for the optimality conditions according to the regression theory (negligible sequential correlation of the residuals assessed by the

Table 6.

Water balance terms $\left(10^{3} \mathrm{~m}^{3} \mathrm{month}^{-1}\right)$ of the conveyance and distribution system.

\begin{tabular}{|c|c|c|c|c|c|c|c|}
\hline Year & Month & Inflow & Outflow & Seepage & Maize irrigation & Rice irrigation & Poplar Irrigation \\
\hline \multirow[t]{4}{*}{2010} & May & 1556 & 54 & 467 & 0 & 1035 & 0 \\
\hline & Jun & 3702 & 130 & 1111 & 257 & 2080 & 124 \\
\hline & Jul & 4211 & 147 & 1263 & 129 & 2671 & 0 \\
\hline & Aug & 3775 & 132 & 1132 & 0 & 2386 & 124 \\
\hline \multirow[t]{4}{*}{2011} & May & 3421 & 120 & 1026 & 0 & 2275 & 0 \\
\hline & Jun & 3784 & 132 & 1135 & 365 & 2037 & 114 \\
\hline & Jul & 4030 & 141 & 1209 & 365 & 2201 & 114 \\
\hline & Aug & 3641 & 127 & 1092 & 183 & 2125 & 114 \\
\hline \multirow[t]{4}{*}{2012} & May & 2143 & 75 & 643 & 0 & 1425 & 0 \\
\hline & Jun & 3303 & 116 & 991 & 532 & 1553 & 112 \\
\hline & Jul & 3491 & 122 & 1047 & 532 & 1678 & 112 \\
\hline & Aug & 3112 & 109 & 933 & 266 & 1691 & 112 \\
\hline \multirow[t]{4}{*}{2013} & May & 940 & 33 & 282 & 0 & 625 & 0 \\
\hline & Jun & 3112 & 109 & 934 & 590 & 1356 & 123 \\
\hline & Jul & 3849 & 135 & 1155 & 590 & 1847 & 123 \\
\hline & Aug & 3811 & 133 & 1143 & 295 & 2116 & 123 \\
\hline \multirow[t]{4}{*}{$2010-2013^{\mathrm{a}}$} & May & $2015( \pm 1059)$ & $71( \pm 37)$ & $605( \pm 318)$ & $0( \pm 0)$ & $1340( \pm 704)$ & $0( \pm 0)$ \\
\hline & Jun & $3475( \pm 32)$ & $122( \pm 11)$ & $1043( \pm 96)$ & $436( \pm 153)$ & $1757( \pm 358)$ & $118( \pm 6)$ \\
\hline & Jul & $3895( \pm 307)$ & $136( \pm 11)$ & $1169( \pm 92)$ & $404( \pm 207)$ & $2099( \pm 439)$ & $87( \pm 58)$ \\
\hline & Aug & $3585( \pm 324)$ & $125( \pm 11)$ & $1075( \pm 97)$ & $186( \pm 133)$ & $2080( \pm 287)$ & $118( \pm 6)$ \\
\hline
\end{tabular}

\footnotetext{
${ }^{\text {a }}$ Averages and standard deviations over the period.
} 
runs test (Bradley, 1968) and the normality of the residuals assessed by the Lilliefors test (Lilliefors, 1967): $p$-values $>0.1$ in both cases). According to the calibrated relationship, the deeper the water table, the greater is the decrease of the groundwater depth in response to a unit percolation. Conversely, when the water table is shallower, the response is flatter, that is, a smaller groundwater depth decrease is observed for the same increase in percolation. This behaviour is in good agreement with the landscape and hydrogeology of the study area, which is crossed by several entrenched river channels draining the aquifer. The lower the groundwater depth, the greater will be the head difference between the aquifer and the channels and then the greater the drainage of these channels.

As usual in case of empirical regressions, the relationship is reliable only within the range of the dataset, while no applications outside this range are to be considered trustworthy. In our study, the quadratic relationship reached its minimum at around $0.60 \mathrm{~m}$ for a percolation of $1.30 \mathrm{~m}$; as the percolation exceeds this value, the estimated groundwater depth starts to increase and the calibrated relationship gives meaningless outcomes. However, in the scenario we are investigating, we expect the percolations to be fairly within the range of the percolations estimated for the present state; i.e., between the low percolations occurring in winter and the high summer values, due to the continuous submergence of rice fields.

\subsection{Predicting the effects of flush irrigation}

\subsubsection{No feedback scenario (NF)}

As expected, the average irrigation requirement for flush irrigated rice $(825 \mathrm{~mm})$ was much smaller than for continuous submergence (3800 mm) (Table 7). The year-to-year variability was quite high, with similar irrigation requirements only in 2011 and 2012 (1350 and $1500 \mathrm{~mm}$, respectively), while no irrigations were applied in 2010 and just $450 \mathrm{~mm}$ were required in 2013. The negligible (2010) or very low (2013) irrigation requirements in the latter years were due primarily to the presence of shallow groundwater (summer minimum depths of $0.60 \mathrm{~m}$ in 2010 and of $0.80 \mathrm{~m}$ in 2013) and, for 2010 only, to the high rainfall amount $(155 \mathrm{~mm})$ received in August.

Results of Table 7 show that the shift from CS to FI determined a significant reduction of the average percolation, which decreased from an average of $3210 \mathrm{~mm}$ to values of about $1100 \mathrm{~mm}$ (mean of the years 2011 and 2012) or even less (years 2010 and 2013) The influence of this drop in the percolation flux on the groundwater depth was not considered in this scenario, but the application of the relationship between percolation flux and groundwater depth of Eq. (7) allowed us to check whether it was significant or not. Providing in input to the equation the series of simulated monthly percolation fluxes of NF scenario for years 2010-2013, we obtained the pattern of

Table 7.

Irrigation amounts (normal font) and percolations (italic font) of the different crops ( $\mathrm{mm}$ ) and the whole district $\left(10^{3} \mathrm{~m}^{3}\right)$ obtained from each scenario in the years $2010-2013$.

\begin{tabular}{|c|c|c|c|c|c|c|}
\hline & Scenarios & Maize & Continuously submerged rice & Flush irrigated rice & Young Poplar & District \\
\hline \multirow[t]{8}{*}{2010} & \multirow[t]{2}{*}{ Present state } & 450 & 3399 & - & 420 & 13244 \\
\hline & & 356 & 2942 & & 49 & 11408 \\
\hline & \multirow[t]{2}{*}{ No feedback } & 450 & - & 0 & 420 & 954 \\
\hline & & 356 & & -67 & 49 & 451 \\
\hline & \multirow[t]{2}{*}{ Feedback accounting-15 ${ }^{\mathrm{a}}$} & 750 & - & 1500 & 630 & 7494 \\
\hline & & 713 & & 1505 & 106 & 6689 \\
\hline & \multirow[t]{2}{*}{ Feedback accounting $-10^{\mathrm{b}}$} & 1050 & - & 1500 & 630 & 7881 \\
\hline & & 986 & & 1505 & 106 & 7039 \\
\hline \multirow[t]{8}{*}{2011} & \multirow[t]{2}{*}{ Present state } & 750 & 3882 & - & 630 & 14877 \\
\hline & & 434 & 3175 & & 73 & 12129 \\
\hline & \multirow[t]{2}{*}{ No feedback } & 750 & - & 1350 & 630 & 6406 \\
\hline & & 430 & & 1113 & 73 & 4952 \\
\hline & \multirow{2}{*}{ Feedback accounting-15 } & 750 & - & 1500 & 630 & 7043 \\
\hline & & 491 & & 1282 & 79 & 5685 \\
\hline & \multirow[t]{2}{*}{ Feedback accounting- $10^{\mathrm{b}}$} & 1050 & - & 1500 & 630 & 7593 \\
\hline & & 768 & & 1282 & 79 & 6188 \\
\hline \multirow[t]{8}{*}{2012} & \multirow[t]{2}{*}{ Present state } & 750 & 3904 & - & 630 & 12049 \\
\hline & & 338 & 3097 & & 60 & 9180 \\
\hline & \multirow[t]{2}{*}{ No feedback } & 750 & - & 1500 & 630 & 6171 \\
\hline & & 338 & & 1164 & 60 & 4195 \\
\hline & \multirow[t]{2}{*}{ Feedback accounting- $15^{\mathrm{a}}$} & 750 & - & 1800 & 630 & 6905 \\
\hline & & 469 & & 1501 & 71 & 5398 \\
\hline & \multirow[t]{2}{*}{ Feedback accounting $-10^{\mathrm{b}}$} & 1050 & - & 1800 & 630 & 7705 \\
\hline & & 714 & & 1501 & 71 & 5980 \\
\hline \multirow[t]{8}{*}{2013} & \multirow[t]{2}{*}{ Present state } & 750 & 4373 & - & 630 & 11711 \\
\hline & & 354 & 3630 & & 62 & 9078 \\
\hline & \multirow[t]{2}{*}{ No feedback } & 750 & - & 450 & 630 & 3693 \\
\hline & & 354 & & 212 & 62 & 1976 \\
\hline & \multirow{2}{*}{ Feedback accounting-15 $5^{\mathrm{a}}$} & 750 & - & 1800 & 630 & 6452 \\
\hline & & 503 & & 1443 & 80 & 5058 \\
\hline & \multirow[t]{2}{*}{ Feedback accounting $-10^{\mathrm{b}}$} & 1050 & - & 1800 & 630 & 7340 \\
\hline & & 759 & & 1443 & 80 & 5742 \\
\hline \multirow[t]{8}{*}{$2010-2013^{\mathrm{c}}$} & \multirow[t]{2}{*}{ Present state } & $675( \pm 150)$ & $3889( \pm 398)$ & - & $577( \pm 105)$ & $12970( \pm 1431)$ \\
\hline & & $371( \pm 43)$ & $3211( \pm 295)$ & & $61( \pm 10)$ & $10449( \pm 1553)$ \\
\hline & \multirow[t]{2}{*}{ No feedback } & $675( \pm 150)$ & - & $825( \pm 719)$ & $577( \pm 105)$ & $4306( \pm 2549)$ \\
\hline & & $371( \pm 43)$ & & $605( \pm 626)$ & $61( \pm 10)$ & $2893( \pm 2061)$ \\
\hline & \multirow[t]{2}{*}{ Feedback accounting- $15^{\mathrm{a}}$} & $750( \pm 0)$ & - & $1650( \pm 173)$ & $630( \pm 0)$ & $6974( \pm 429)$ \\
\hline & & $544( \pm 114)$ & & $1433( \pm 104)$ & $84( \pm 15)$ & $5708( \pm 703)$ \\
\hline & \multirow[t]{2}{*}{ Feedback accounting $-10^{\mathrm{b}}$} & $1050( \pm 0)$ & - & $1650( \pm 173)$ & $630( \pm 0)$ & $7629( \pm 226)$ \\
\hline & & $807( \pm 122)$ & & $1433( \pm 104)$ & $84( \pm 15)$ & $6237( \pm 565)$ \\
\hline
\end{tabular}

\footnotetext{
a Length of the irrigation turn for maize equal to 15 days.

${ }^{b}$ Length of the irrigation turn for maize equal to 10 days.

${ }^{c}$ Averages and standard deviations over the period.
} 
groundwater depths shown in Fig. 5 panel a. If the effects of the lower percolation were negligible, then this a posteriori pattern should be very similar to the one of measured groundwater depths in the present state (i.e. with CS rice) that was used as bottom boundary condition to estimate irrigation requirements and percolation fluxes in NF scenario. The more the two patterns deviated from each other, the more the percolation fluxes from FI rice were inconsistent with the groundwater depths in the present state. Indeed, Fig. 5 panel a shows that the deviation was quite large, with the a posteriori pattern much deeper than the present state groundwater depths during the whole irrigation season of all years. The largest discrepancies occurred in 2010, when the present state groundwater depths were lower and, hence, the estimated irrigation requirements and the percolation fluxes were very small. These reduced percolation fluxes were largely insufficient to maintain the present state groundwater depths, with an estimated drop of more than one meter in July and August.

\subsubsection{Feedback accounting scenarios (FA-15 and FA-10)}

The patterns of groundwater depths of FA-15 scenario in the four years of the simulation period for the best fitting a priori variant (continuous line) and a posteriori pattern (dashed line) showed a good fitting (Fig. 5 panel b). This is especially clear during the crucial months of the agricultural season, when the summer peaks were very similar in all years. The agreement between the two patterns, as measured by the correlation coefficient $\left(\mathrm{R}^{2}=0.50\right)$ and by the Nash-Sutcliffe index $(\mathrm{N}-\mathrm{S}=0.41)$, was satisfactory. The groundwater depth during the summer months was, on average, about $35 \mathrm{~cm}$ greater in FA-15 scenario than in the present state, due to lower percolation fluxes from FI rice than from CS rice. Under these modified conditions, the 15-day rotation of maize irrigation, which enabled to satisfy almost completely the crop water requirements under the present state, was found to be no longer adequate, as shown by values of average transpiration rates in the critical month of July that were always lower than 0.80 . Shortening the turn from 15 to 10 days (FA-10 scenario) increased the ratio of actual transpiration over potential transpiration of maize by $9 \%$ on average, with values close to 0.90 in all years. At the same time, mature poplars benefitted from the modified situation (ratio of actual transpiration to potential transpiration increased from 0.81 to 0.87 ), as the increased maize irrigation lowered the groundwater depth, allowing higher retention of soil moisture in the rooted soil layer and greater uptake from groundwater. The agreement between the a priori variant and a posteriori pattern of groundwater depths for the FA-10 scenario was similar to the one obtained for the FA-15, with correlation coefficient $\mathrm{R}^{2}$ of 0.52 and Nash-Sutcliffe index of 0.42 .

Irrigation requirements of maize increased from $750 \mathrm{~mm}$ per season (i.e. 5 irrigations) in FA-15 to $1050 \mathrm{~mm}$ (i.e. 7 irrigations) per season in FA-10 (Table 7). The irrigation requirements for FI rice were $1350 \mathrm{~mm}$ in 2010 (9 irrigations) and $1800 \mathrm{~mm}$ in 2013 (12 irrigations), provided approximately on a weekly basis. District water withdrawals under FA-10 scenario were estimated to be on average $41 \%$ less than the present state, while in the FA-15 and NF scenarios, they were lower by $46 \%$ and $67 \%$ respectively. In both scenarios, the time pattern of irrigation requirements of FI rice was always lower than the one of CS rice, but it was more variable in time, with more pronounced summer peak values that tend to be in phase with maize peak requirements. Quite remarkably, this led to a much less pronounced reduction of the withdrawals in July, which generally corresponds to the peak irrigation demand, than what obtained during the whole season $(-24 \%$ against $-41 \%)$.

\subsection{Water use efficiencies of the present state and the scenarios}

Continuously submerged rice had the lowest water use efficiency (WUE $=0.15$ on average, determined as ET divided by irrigation plus rainfall) due to the need of continuously supplying water to maintain ponding water over a coarse soil (Table 8). It follows that WUE of the district in the present state reflected that of CS rice ( 0.17 on average), due to the large area occupied by CS rice (up to $48 \%$ in 2010 ). The WUE of maize was about 0.50 , due to the combination of the soil type, groundwater depth and the use of border irrigation with a fixed rotation scheme.

Assuming a conversion from CS rice to FI rice and no changes in the groundwater depth from the present state (NF scenario), the WUE of rice increased to 0.47 and WUE referred to the whole district reached 0.38 (Table 8 ). Results obtained for FI rice were within ranges reported in literature for field-scale studies (Bouman et al., 2005).

Table 8.

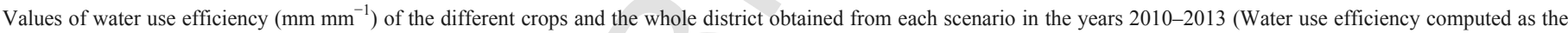
ratio between actual evapotranspiration divided by the sum of irrigation and rainfall).

\begin{tabular}{|c|c|c|c|c|c|c|}
\hline & Scenarios & Maize & Continuously submerged rice & Flush irrigated rice & Young Poplar & District \\
\hline \multirow[t]{4}{*}{2010} & Present state & 0.43 & 0.14 & - & 0.42 & 0.14 \\
\hline & No feedback & 0.43 & - & 0.84 & 0.42 & 0.57 \\
\hline & Feedback accounting-15 ${ }^{\mathrm{a}}$ & 0.34 & - & 0.17 & 0.26 & 0.17 \\
\hline & Feedback accounting-10 $\mathrm{b}$ & 0.29 & - & 0.17 & 0.26 & 0.16 \\
\hline \multirow[t]{4}{*}{2011} & Present state & 0.47 & 0.15 & - & 0.25 & 0.15 \\
\hline & No feedback & 0.47 & - & 0.24 & 0.25 & 0.24 \\
\hline & Feedback accounting $-15^{\mathrm{a}}$ & 0.45 & - & 0.22 & 0.24 & 0.22 \\
\hline & Feedback accounting-10 ${ }^{\mathrm{b}}$ & 0.35 & - & 0.22 & 0.24 & 0.20 \\
\hline \multirow[t]{4}{*}{2012} & Present state & 0.53 & 0.16 & - & 0.27 & 0.18 \\
\hline & No feedback & 0.53 & - & 0.24 & 0.27 & 0.28 \\
\hline & Feedback accounting $-15^{\mathrm{a}}$ & 0.46 & - & 0.21 & 0.24 & 0.23 \\
\hline & Feedback accounting $-10^{\mathrm{b}}$ & 0.39 & - & 0.21 & 0.25 & 0.22 \\
\hline \multirow[t]{4}{*}{2013} & Present state & 0.54 & 0.14 & & 0.30 & 0.19 \\
\hline & No feedback & 0.54 & - & 0.56 & 0.30 & 0.44 \\
\hline & Feedback accounting- $15^{\mathrm{a}}$ & 0.47 & - & 0.21 & 0.25 & 0.25 \\
\hline & Feedback accounting- $10^{\mathrm{b}}$ & 0.40 & - & 0.21 & 0.26 & 0.24 \\
\hline \multirow[t]{4}{*}{$2010-2013^{\mathrm{c}}$} & Present state & $0.49( \pm 0.05)$ & $0.15( \pm 0.01)$ & - & $0.31( \pm 0.08)$ & $0.17( \pm 0.03)$ \\
\hline & No feedback & $0.49( \pm 0.05)$ & - & $0.47( \pm 0.29)$ & $0.31( \pm 0.08)$ & $0.38( \pm 0.15)$ \\
\hline & Feedback accounting-15 & $0.43( \pm 0.06)$ & - & $0.20( \pm 0.02)$ & $0.25( \pm 0.01)$ & $0.22( \pm 0.04)$ \\
\hline & Feedback accounting-10 $\mathrm{b}$ & $0.36( \pm 0.05)$ & - & $0.20( \pm 0.02)$ & $0.25( \pm 0.01)$ & $0.21( \pm 0.03)$ \\
\hline
\end{tabular}

\footnotetext{
${ }^{\text {a }}$ Length of the irrigation turn for maize equal to 15 days.

${ }^{b}$ Length of the irrigation turn for maize equal to 10 days.

c Averages and standard deviations.
} 
When the feedback effects between irrigation and groundwater depth were accounted for (FA-15 and FA-10 scenarios), the WUE of FI rice decreased to an average of 0.20 , being just $5 \%$ higher than CS rice. In contrast to the increase in WUE for FI rice, maize WUE decreased from an average of 0.49 in the present state to 0.36 in FA-10, due to the need of shortening the irrigation turn. Considering again the whole district, WUE under FA-10 scenario was 0.21 against 0.17 in the present state

\section{Conclusions}

According to numerous field-scale studies, flush irrigation management in rice farming has the potential to significantly reduce the irrigation requirements of continuous flooding. However, when such technique is adopted over large paddy areas, the reduction in water withdrawals may be of different extent due to the effects on groundwater resources caused by decreased recharge. In areas with shallow groundwater, a decrease of tens of centimetres may have an impact on the irrigation requirements due to the reduction of capillary rise contribution and the increase in percolation.

In the case of the S. Giorgio East district, the reduction in water withdrawals for rice declined from around $80 \%$ when no feedback between groundwater depth and recharge was considered, to around $60 \%$ when feedbacks were accounted for. Moreover, changes in the irrigation method of rice determined variations in the irrigation requirements of maize, due to the same reasons. The current irrigation scheduling of maize, based on a 15-day rotation was found to be insufficient for satisfying crop water requirements in the scenario of flush irrigated rice, in which groundwater depths were higher. A reduction of the rotation to 10 days practically eliminated transpiration stress, but it increased the irrigation requirements of maize by about $50 \%$. In addition, the time pattern of irrigation requirements of flush irrigated rice was more variable than that of continuously submerged rice, with the peak value generally occurring in July, as is the case also for maize. Therefore, the reduction in simulated district irrigation deliveries in July (about $-25 \%$ ) was much smaller than reductions observed over the whole period (about $-40 \%$ ). These results suggest that the reduction in irrigation deliveries to rice fields, when changing from continuously submerged to flush irrigated rice, might increase the irrigation requirement of other crops, due to the feedback effects of groundwater dynamics at larger scales, and amplify the variability of total irrigation requirements during the agricultural season.

Gains in water use efficiency at both the field and the district level are possible after a conversion to flush irrigated rice. In our study, the water use efficiency of the district was estimated to be about $5 \%$ greater than that of the present state, in contrast to an improvement of almost $20 \%$ when groundwater depths were assumed to remain unvaried after changes in the water management of rice.

Our results show that the role of feedbacks is particularly relevant in the S. Giorgio-E district, where soils are highly permeable. In areas with less permeable soils, results might be different. In sum, we do not imply that flush irrigation is ineffective. Rather, we stress the importance of carefully analysing the regional hydrologic consequences of a large conversion from continuous submergence to flush irrigated rice and, eventually, various other issues that we have not addressed, including possible yield gaps between submerged rice and flush irrigated rice, changes in nutrient and pesticide dynamics in aerobic soil conditions and the loss of ecosystem services maintained by the continuous flooding of rice paddies.

\section{Uncited references}

Bouman and Tuong (2001), Masseroni et al. (2013) and Molden (1997).

\section{Acknowledgements}

We gratefully acknowledge Regione Lombardia and MIUR for funding the study through the Biogesteca Project: "Piattaforma di biotecnologie verdi e di tecniche gestionali per un sistema agricolo ad elevata sostenibilità ambientale" and the PRIN 2010-2011 project "Traditional agricultural landscapes in Italy: multi-disciplinary and multi-scale assessment for the development of an integrated model for landscape planning and management", respectively. We wish also to thank AIES and ARPA Lombardia for providing data and information on the pilot study area. We appreciate also the helpful comments and suggestions provided by two anonymous reviewers.

\section{References}

Allen, R.G., Pereira, L.S., Raes, D., Smith, M., 1998. Crop evapotranspiration — guidelines for computing crop water requirements. FAO Irrigation and Drainage Paper 56 Food and Agriculture Organization, Rome.

Baroni, G., Facchi, A., Gandolfi, C., Ortuani, B., Horeschi, D., van Dam, J.C., 2010. Uncertainty in the determination of soil hydraulic parameters and its influence on the performance of two hydrological models of different complexity. Hydrol. Earth Syst. Sci. 14, 251-270.

Baumer, O.W., 1990. Prediction of soil hydraulic parameters. In: Proceedings of International Workshop in Indirect Methods for-Estimating the Hydraulic Properties of Unsaturated Soils. USDA-ARS/University of California, Riverside, CA. .

Belder, P., Bouman, B.A.M., Cabangon, R., Lu, G., Quilang, E.J.P., Li, Y., Spiertz, J.H.J., Tuong, T.P., 2004. Effect of water-saving irrigation on rice yield and water use in typical lowland conditions in Asia. Agric. Water Manage. 65, 193-210.

Belder, P., Spiertz, J.H.J., Bouman, B.A.M., Lu, G., Tuong, T.P., 2005. Nitrogen economy and water productivity of lowland rice under water-saving irrigation. Field Crop Res. 93, 169-185.

Belder, P., Bouman, B.A.M., Spiertz, J.H.J., 2007. Exploring options for water savings in lowland rice using a modelling approach. Agric. Syst. 92, 91-114.

BioGesteca, 2014. Quaderno Gestione Della Risorsa Irrigua Biogesteca Project Founded by Regione Lombardia. Regione Lombardia, Italy. http://www.enterisi.it/upload/ enterisi/documentiallegati/ PROVOLOBiogesteca\%20Mortara\%20gennaio\%202014p 13660 248.pdf.

Borrell, A., Garside, A., Fukai, S., 1997. Improving efficiency of water use for irrigated rice in a semi-arid tropical environment. Field Crop Res. 52, 231-248.

Bouman, B.A.M., Peng, S., Castañeda, A.R., Visperas, R.M., 2005. Yield and water use of irrigated tropical aerobic rice systems. Agric. Water Manage. 74, 87-105.

Bouman, B.A.M., Feng, L., Tuong, T.P., Lu, G., Wang, H., Feng, Y., 2007. Exploring options to grow rice using less water in northern China using a modelling approach II. Quantifying yield water balance components, and water productivity. Agric. Water Manage. 88, 23-33.

Bradley, J.V., 1968. Distribution-Free Statistical Tests Prentice. Hall Englewood Cliffs, New York.

Cabangon, R.J., Tuong, T.P., Castillo, E.G., Bao, L.X., Lu, G., Wang, G.H., Cui, Y., Bouman, B.A.M., Li, Y., Chen, C., Wang, J., 2004. Effect of irrigation method and Nfertilizer management on rice yield: water productivity and nutrient-use efficiencies in typical lowland rice conditions in China. Paddy Water Environ. 2, 195-206.

Chiaradia, E.A., Facchi, A., Masseroni, D., Ferrari, D., Bischetti, G.B., Gharsallah, O. Cesari de Maria, S., Romani, M., Gandolfi, C., 2015. An integrated, multi-sensor system for the continuous monitoring of water dynamics in rice fields under different irrigation regimes. Environ. Monit. Assess. 187 (9), 586. http://dx.doi.org/10.1007/ s10661-015-4796.

ENR, 2013. XLVI Relazione Annuale Anno 2013. Ente Nazionale Risi. Il Risicoltore. . (access: March 2015) http://www.enterisi.it/upload/enterisi/bilanci/ Relazione\%20Annuale\%202013\%20low_15916_163.pdf.

ERSAL, 1993. I suoli della Lomellina Settentrionale. Progetto Carta Pedologica. Regione Lombardia, Ente Regionale di Sviluppo Agricolo della Lombardia.

Facchi, A., Gharsallah, O., Chiaradia, E.A., Bischetti, G.B., Gandolfi, C., 2013. Monitoring and modelling evapotranspiration in flooded and aerobic rice fields: in: four decades of progress in monitoring and modeling of processes in the Soil-Plant-Atmosphere System: applications and challenges. Proc. Environ. Sci. 19, , 794-803.

Facchi, A., Gharsallah, O., Gandolfi, C., 2013. Evapotranspiration models for a maize agro-ecosystem in irrigated and rainfed conditions. Abstract in the Proceedings of the 10th Conference of the Italian Society of Agricultural Engineering: Horizons in 
Agricultural, Forestry and Biosystems Engineering. Viterbo (Italy): September 2013. J. Agric. Eng. , 8-12. XLIV(s2).

Feddes, R.A., Kowalik, P.J., Zaradny, H., 1978. Simulation of field water use and crop yield. Simulation Monographs. Pudoc, Wageningen. (189 pp.).

Feng, L., Bouman, B.A.M., Tuong, T.P., Cabangon, R.J., Li, Y., Lu, G., Feng, Y., 2007. Exploring options to grow rice using less water in northern China using a modelling approach I. Field experiments and model evaluation. Agr. Water Manage. $88,1-13$.

Fernando, C.H., Goltenboth, F., Margraf, J., 2005. Aquatic Ecology of Ricefields. Volumes Publishing, Kitchener Ontario, Canada. 472 p.

Govindarajan, S., Ambujam, N.K., Karunakaran, K., 2008. Estimation of paddy water productivity (WP) using hydrological model: an experimental study. Paddy Water Environ. 6, 327-339.

Guerra, L.C., Bhuiyan, S.I., Tuong, T.P., Barker, R., 1998. Producing more rice with less water. SWIM Paper 5. International Water Management Institute, Colombo, Sri Lanka.

Humphreys, E., Meisner, C., Gupta, R., Timsina, J., Beecher, H.G., Tang Yong, Lu, Singh, Yadvinder, Gill, M.A., Masih, I., Jia Guo, Zheng, Thompson, J.A., 2005. Water saving in rice-wheat systems. Plant Prod. Sci. 8 (3), 242-258.

INEA, 2013. In: Roma, Lupia F. (Ed.), A Model-Based Irrigation Water Consumption Estimation at Farm Level. INEA, p. 173 (ISBN 978-88-8145-289-7).

Köppen, W., 1936. Das geographische System der Klimate. Handbuch der Klimatologie In: Köppen, W., and Geiger, R. (Eds.), Verlag von Gebrüder Borntraeger, Berlin vol. 1 Part C pp. 1-44, 4.

Kato, Y., Okami, M., Katsura, K., 2009. Yield potential and water use efficiency of aerobic rice (Oryza sativa L.) in Japan. Field Crop Res. 113, 328-334. Kroes, J.G., van Dam, J.C., 2003. Reference Manual SWAP version 3.0.3. Alterrareport 773. Wageningen, A lterra, Green World Research. ISSN 1566-7197.

Kroes, J.G., Van Dam, J.C., Groenendijk, P., Hendriks, R.F.A., Jacobs, C.M.J., 2008. SWAP version 3.2. Theory description and user manual. Wageningen, Alterra, $\mathrm{Al}$ terra Report1649 (02)—Swap32 Theory description and user manual.doc. http:// www.swap.alterra.nl/DownloadRecent/swap32(36)/Swap32(36).htm.

Lilliefors, H., 1967. On the Kolmogorov-Smirnov test for normality with mean and variance unknown. J. Am. Stat. Assoc. 62, 399-402.

L. Lv, T.E. Franz, D.A. Robinson, S.B. Jones, Measured and modeled soil moisture compared with cosmic-ray neutron probe estimates in a mixed forest, Vadose Zone J. 3 (12) (2014) 13, http://dx.doi.org/10.2136/vzj2014.06.0077.

Mishra, H.S., Rathore, T.R., Pant, R.C., 1990. Effect of intermittent irrigation on groundwater table contribution: irrigation requirements and yield of rice in mollisols of Tarai Region. Agric. Water Manage. 18, 231-241.

Rienzner, M., Cesari de Maria, S., Facchi, A., Wassar, F., Gandolfi, C., 2013. Estimating the contribution of rainfall, irrigation and upward soil water flux to crop water requirements of a maize agroecosystem in the Lombardy plain. Abstract in the Proceedings of the 10th Conference of the Italian Society of Agricultural Engineering. Viterbo (Italy): September 2013. J. Agric. Eng. 8-12. XLIV(s2).

Schaap, M.G., Leij, F.J., van Genuchten, M.Th., 2001. ROSETTA: A computer program for estimating soil hydraulic parameters with hierarchical pedotransfer functions. J. Hydrol. 251, 163-176.

Singh, R., Kroes, J.G., van Dam, J.C., Feddes, R.A., 2006. Distributed ecohydrologichal modelling to evaluate the performance of irrigation in Sirsa District, India: I. Current water management and its productivity. J. Hydrol. 329, 692-713.

Tabbal, D.F., Bouman, B.A.M., Bhuiyan, S.I., Sibayan, E.B., Sattar, M.A., 2002. Onfarm strategies for reducing water input in irrigated rice; case studies in the Philippines. Agric. Water Manage. 56, 93-112.

USDA, 1975. Soil Taxonomy, 1st ed. Soil Survey Staff, United States Department of Agriculture, Natural Resources Conservation Serv. 